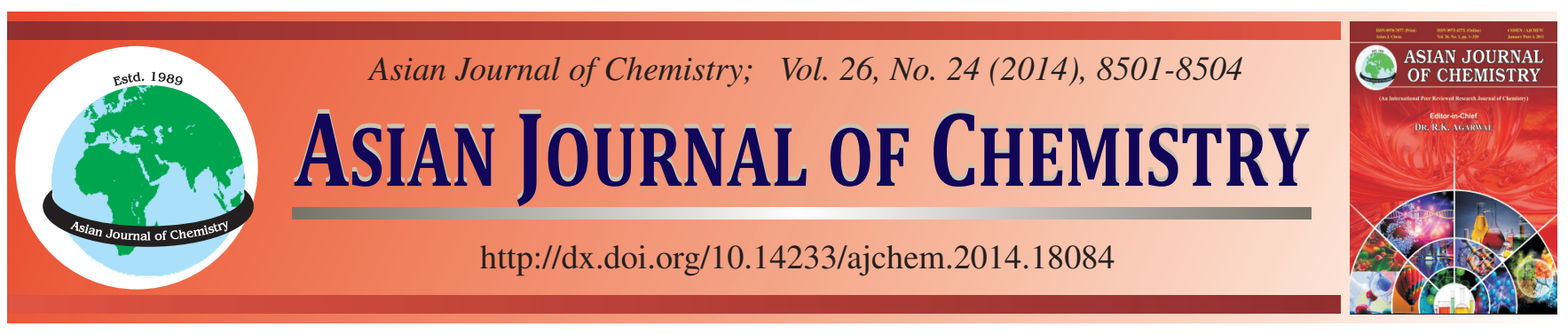

\title{
Novel Thioureido Derivatives Carrying Thione and Sulfonamide Moieties Induce the Cytoprotective Enzyme NAD(P)H:Quinone Oxidoreductase 1
}

\begin{abstract}
Mostafa M. Ghorab ${ }^{1, *}$, Maureen Higgins ${ }^{2}$, Albena T. Dinkova-Kostova ${ }^{2,3, *}$, Mansour S. Alsaid ${ }^{1}$ and Abdelaaty A. Shahat ${ }^{1,4}$
${ }^{1}$ Department of Pharmacognosy, College of Pharmacy, King Saud University, P.O. Box 2457, Riyadh 11451, Kingdom of Saudi Arabia ${ }^{2}$ Jacqui Wood Cancer Centre, Division of Cancer Research, Medical Research Institute, University of Dundee, Dundee DD1 9SY, United Kingdom ${ }^{3}$ Departments of Medicine and Pharmacology and Molecular Sciences, Johns Hopkins University School of Medicine, Baltimore, MD 21205, USA ${ }^{4}$ Phytochemistry Department, National Research Centre, 12311 Dokki, Cairo, Egypt
\end{abstract}

*Corresponding authors: Fax: +966 1 4670560; Tel: +966 534292860; E-mail: mmsghorab@yahoo.com

Plant-derived molecules have played an important role for the prevention and treatment of cancer. On the account of the reported anticancer activity of quinazolines containing the biologically active sulfonamide moieties, a novel series of thioureido and quinazoline derivatives were synthesized using methyl 2-isothiocyanatobenzoate (2) as a strategic starting material. The present work reports the synthesis and $\mathrm{NAD}(\mathrm{P}) \mathrm{H}$ :quinone oxidoreducase 1 (NQO1) inducer activity of three novel thioureido and quinazoline derivatives $\mathbf{3}, \mathbf{4}$ and $\mathbf{5}$. The thioureido derivative $\mathbf{3}$ was obtained in good yield via reaction of compound $\mathbf{2}$ with sulfaphenazole in absolute ethanol at room temperature. Reaction of compound $\mathbf{2}$ with sulfaphenazole and/ or sulfadimethoxazine in absolute ethanol containing a catalytic amount of triethylamine furnished the corresponding sulfonamide derivatives $\mathbf{4}$ and $\mathbf{5}$, respectively. The structure of the newly synthesized compounds was confirmed on the basis of elemental analyses, IR, ${ }^{1} \mathrm{H}$ NMR and ${ }^{13} \mathrm{C}$ NMR spectra. Evaluation of the NQO1 enzyme activity in murine cells exposed to the new compounds revealed that introduction of the thioureido moiety confers inducer activity. Furthermore, incorporating the thioureido moiety within a heterocyclic ring system increases the inducer potency.

Keywords: Synthesis, Thioureido, Quinazoline, NQO1, Electrophilicity, Cytoprotection.

\section{INTRODUCTION}

Considerable attention has been devoted to the construction of new derivatives of thioureido and quinazolines, on account of their reported biological activities ${ }^{1-8}$. Several methods have been described for the elaboration of substituted sulfonamides ${ }^{9-11}$, which as a class have been reported to have cytotoxic and anticancer activity. Although tremendous progress has been achieved in the development of novel cancer treatments. Most of the current drugs exhibit high toxicity and drug resistance by tumor cells frequently develops. This dilemma is particularly true for DNA-damaging agents, the mainstay of cancer treatment ${ }^{12}$. Quinazolines have been reported to possess several pharmacological properties, including anticancer activity ${ }^{13-17}$. It was also found that the acetamide derivatives constitute an important class of drugs, with several types of pharmacological agents possessing anticancer activity ${ }^{18-21}$. A large number of structurally novel quinazolines have been reported to show substantial anticancer activity in vitro and in vivo $^{22}$.

Several mechanisms have been proposed for the anticancer activity of the quinazoline sulfonamide compounds ${ }^{23-27}$. The most prominent of these mechanisms involves inhibition of carbonic anhydrase (CA) and it was suggested by Chegwidden and Spencer $^{27}$ that these compounds may reduce the provision of bicarbonate for the synthesis of nucleotides and other essential cellular components, such as membrane lipids. The objective of this study was to design and synthesize sulfonamide compounds which could potentially be developed as cancer chemopreventive agents. We have recently shown that sulfonamide compounds which bear electrophilic Michael acceptor enone or cyanoenone functionalities have the ability to induce NAD(P)H:quinone oxidoreducase 1 (NQO1) ${ }^{28}$. NQO1 is an enzyme with a broad range of cytoprotective activities ${ }^{29,30}$. The gene expression of NQO1 can be upregulated by a number of small molecule activators (inducers), through the Keap1/ Nrf2 pathway ${ }^{31}$. Under basal conditions, Keap1, a substrate adaptor protein for Cullin3/Rbx1-based ubiquitin ligase, continuously targets transcription factor Nrf 2 for ubiquitination and degradation. Inducers react with cysteine sensors of Keap1, which loses its repressor activity, leading to Nrf2 accumulation and activation of transcription of its downstream target genes, including NQO1. Small molecule Nrf2 activators, such as the plant-derived isothiocyanates, which have been identified 
based on their ability to induce NQO1, have subsequently shown protective effects in numerous animal models of chemical as well as genetic carcinogenesis, at various organ sites ${ }^{32}$. Based on the above information and as a continuation of previous work on anticancer agents ${ }^{33-39}$, we hypothesized that introduction of the sulfhydryl-reactive thioureido moiety will confer NQO1 inducer activity. Indeed, inducers of NQO1 have one common property: reactivity with sulfhydryl groups. As NQO1 is a marker cytoprotective enzyme which is upregulated by chemopreventive compounds, information of the structural features required for NQO1 inducer activity is important for the future development of agents for cancer prevention.

\section{EXPERIMENTAL}

The starting material methylanthranilate (1) and thiophsogen were purchased from Sigma-Aldrich. Melting points were determined on an electrothermal melting point apparatus (Stuart Scientific, Stone) and were uncorrected. Precoated Silica gel plates (Kiesel gel $0.25 \mathrm{~mm}, 60 \mathrm{G} \mathrm{F} 254$, Merck) were used for thin layer chromatography (TLC). The developing solvent system was chloroform/methanol (10: 3 ) and the spot were detected by ultraviolet light. IR spectra $(\mathrm{KBr}$ disc) were recorded on FT-IR spectrophotometer (Perkin Elmer) at the Research Center, College of Pharmacy, King Saud University, Saudi Arabia. ${ }^{1} \mathrm{H}$ NMR spectra were scanned in dimethyl sulfoxide (DMSO- $d_{6}$ ) on a NMR spectrophotometer (Bruker AXS Inc.) operating at $500 \mathrm{MHz}$ for ${ }^{1} \mathrm{H}$ and $125.76 \mathrm{MHz}$ for ${ }^{13} \mathrm{C}$ at the aforementioned Research Center. Chemical shifts are expressed in $\delta$ values (ppm) relative to tetramethylsilane (TMS) as an internal standard. Exchangeable protons were confirmed by addition of drop of $\mathrm{D}_{2} \mathrm{O}$. Elemental analyses were done on a model 2400 CHNSO analyzer (Perkin Elmer).

Synthesis of methyl 2-(3-(4-(N-(1-phenyl-1H-pyrazol5-yl)sulfamoyl)-phenyl)-thioureido)-benzoate (3): A mixture of compound 2 (1.93 g, 0.01 mole) and 4-amino- $N$-(1-phenyl$1 H$-pyrazol-5-yl)benzenesulfonamide ( $3.14 \mathrm{~g}, 0.01 \mathrm{~mole})$ in absolute ethanol $(30 \mathrm{~mL})$ was stirred at room temperature for $5 \mathrm{~h}$. The reaction mixture was poured onto ice water and the solid obtained was recrystallized from dioxane to give $\mathbf{3}$. Yield $\%$ 88; m.p. $322.9^{\circ} \mathrm{C}$; IR ( $\left.\mathrm{KBr}, v_{\max }, \mathrm{Cm}^{-1}\right)$ : 3448, 3275(NH), 3039 (CH arom.), 2977, 2863 (CH aliph.), 1662 (C=O), 1620 $(\mathrm{C}=\mathrm{N}), 1342,1168\left(\mathrm{SO}_{2}\right), 1261(\mathrm{C}=\mathrm{S}) .{ }^{1} \mathrm{H}$ NMR spectrum in $\left(\mathrm{DMSO}-d_{6}\right)$ : $4.21\left[\mathrm{~s}, 3 \mathrm{H}, \mathrm{OCH}_{3}\right], 6.60,7.64[2 \mathrm{~d}, 2 \mathrm{H}, 2 \mathrm{CH}$ pyrazole, $J=7.33 \mathrm{~Hz}$ ], 7.08- 8.12 [m, 13H, Ar-H], 11.46 [s, $1 \mathrm{H}, \mathrm{SO}_{2} \mathrm{NH}, \mathrm{D}_{2} \mathrm{O}$-exchangeable], $12.95\left[\mathrm{~s}, 2 \mathrm{H}, 2 \mathrm{NH}, \mathrm{D}_{2} \mathrm{O}-\right.$ exchangeable]. ${ }^{13} \mathrm{C}$ NMR spectrum (in DMSO- $d_{6}$ ): 52.4, 95.6, 121.3 (2), 121.8, 127.9 (2), 128.5 (2), 129.0 (2), 131.4, 132.6, 134.3, 137.8, 139.6, 141.2, 141.8, 144.9, 168.1, 181.2. Anal. Calc. for $\mathrm{C}_{24} \mathrm{H}_{21} \mathrm{~N}_{5} \mathrm{O}_{4} \mathrm{~S}_{2}$ (508): C, 56.79; H, 4.17; N, 13.80; found: C, 56.42; H, 4.34; N, 13.49 .

Synthesis of 4-(4-oxo-2-thioxo-1,2-dihydroquinazolin3(4H)-yl)- $\mathrm{N}$-(1-phenyl-1H-pyrazol-5-yl)benzenesulfonamide (4): A mixture of compound 2 (1.93 g, 0.01 mole) and 4-amino- $N$-(1-phenyl-1 $H$-pyrazol-5-yl)benzenesulfonamide $(3.14 \mathrm{~g}, 0.01 \mathrm{~mole})$ in absolute ethanol $(30 \mathrm{~mL})$ containing a catalytic amount of triethylamine was refluxed for $18 \mathrm{~h}$. The reaction mixture was cooled and poured onto ice water and the solid obtained was recrystallized from dioxane to give 4 .
Yield \% 90; m.p. $300.4{ }^{\circ} \mathrm{C}$; IR (KBr, $\left.v_{\max }, \mathrm{Cm}^{-1}\right): 3307,3210$ (NH), 3088 (CH arom.), $1688(\mathrm{C}=\mathrm{O}), 1610(\mathrm{C}=\mathrm{N}), 1365,1155$ $\left(\mathrm{SO}_{2}\right), 1272(\mathrm{C}=\mathrm{S}) .{ }^{1} \mathrm{H}$ NMR spectrum (in DMSO-d $)$ : 6.44, $7.41[2 \mathrm{~d}, 2 \mathrm{H}, 2 \mathrm{CH}$ pyrazole, $J=6.97 \mathrm{~Hz}], 7.05-8.23[\mathrm{~m}, 13 \mathrm{H}$, Ar-H], 9.35 [s, 1H, NH, D 2 -exchangeable], 11.44 [s, 1H, $\mathrm{SO}_{2} \mathrm{NH}, \mathrm{D}_{2} \mathrm{O}$-exchangeable]. ${ }^{13} \mathrm{C}$ NMR spectrum (in DMSO$\left.d_{6}\right)$ : 91.7, $119.8(2), 120.6(2), 122.7,124.6,125.1,126.8$ (2), 127.6, 127.9, 128.5 (2), 130.6, 134.1, 134.7, 140.4, 141.3, 141.9, 144.8, 162.7, 187.3. Anal. Calc. for $\mathrm{C}_{23} \mathrm{H}_{17} \mathrm{~N}_{5} \mathrm{O}_{3} \mathrm{~S}_{2}$ (476): C, 58.09; H, 3.60; N, 14.73; found: C, 58.32; H, 3.31; N, 14.51 .

Synthesis of $N$-(2,6-dimethoxypyrimidin-4-yl)-4-(4oxo-2-thioxo-1,2-dihydro-quinazolin-3(4H)-yl)benzenesulfonamide (5): A mixture of compound 2 (1.93 g, 0.01 mole) and 4-amino- $N$-(3,5-dimethoxy-phenyl)benzenesulfonamide (3.08 g, 0.01 mole) in absolute ethanol $(30 \mathrm{~mL})$ containing a catalytic amount of triethylamine was refluxed for $15 \mathrm{~h}$. The reaction mixture was cooled and poured onto ice water and the solid obtained was recrystallized from $\mathrm{DMF} / \mathrm{EtOH}$ to give 5. Yield \% 84; m.p. $219.1{ }^{\circ} \mathrm{C}$; IR (KBr, $\left.v_{\max }, \mathrm{Cm}^{-1}\right)$ : 3216, 3194 (NH), 3065 (CH arom.), $1691(\mathrm{C}=\mathrm{O}), 1622(\mathrm{C}=\mathrm{N}), 1357,1163$ $\left(\mathrm{SO}_{2}\right), 1265(\mathrm{C}=\mathrm{S}) .{ }^{1} \mathrm{H}$ NMR spectrum (in DMSO- $\left.d_{6}\right): 3.62$, 3.74 [2s, $6 \mathrm{H}, 2 \mathrm{OCH}_{3}$ ], 6.26 [s, $1 \mathrm{H}, \mathrm{CH}$ pyrimidine], 7.13-8.28 [m, $8 \mathrm{H}, \mathrm{Ar}-\mathrm{H}$ ], 8.93 [s, 1H, NH, $\mathrm{D}_{2} \mathrm{O}$-exchangeable], 10.90 [s, $1 \mathrm{H}, \mathrm{SO}_{2} \mathrm{NH}, \mathrm{D}_{2} \mathrm{O}$-exchangeable]. ${ }^{13} \mathrm{C} \mathrm{NMR}$ spectrum (in DMSO- $\left.d_{6}\right)$ : $56.6(2), 84.3,120.8(2), 122.6,125.7,126.3$ (2), 126.9, 127.8, 129.8, 134.6, 134.9, 138.4, 161.3, 161.7, 163.2, 174.1, 187.8. Anal. Calc. for $\mathrm{C}_{20} \mathrm{H}_{17} \mathrm{~N}_{5} \mathrm{O}_{5} \mathrm{~S}_{2}$ (472): C, 50. 95; H, 3.63; N, 14.85; found: C, 50.66; H, 3.29; N, 14.49.

Biological evaluation: The NQO1 inducer activity was evaluated using a microtiter plate assay developed by Prochaska and colleagues ${ }^{40}$. Hepa1c1c7 murine hepatoma cells were maintained in a humidified atmosphere at $37{ }^{\circ} \mathrm{C}, 5 \% \mathrm{CO}_{2}$. The cell culture medium was $\alpha$ MEM supplemented with $10 \%$ (v/v) heat- and charcoal-inactivated fetal bovine serum. Cells $\left(10^{4}\right.$ per well) in 96-well plates were grown for $24 \mathrm{~h}$ and then exposed in 8 replicates to 8 serial dilutions of compounds for $48 \mathrm{~h}$. Compounds were prepared as stock solutions in DMSO and then diluted in the medium 1:1000. The final concentration of DMSO in the cell culture medium was maintained at $0.1 \%$ $(\mathrm{v} / \mathrm{v})$ in all wells. At the end of the incubation period, cells were lysed and the specific activity of NQO1 was evaluated in cell lysates using menadione as a substrate. The concentration which doubles the specific activity of NQO1 (CD value) was used to quantify inducer potency. Protein concentrations were determined in aliquots from the cell lysates by the bicinchoninic acid (BCA) assay (Thermo Scientific). A decrease in protein concentration of the cell lysates was used as an indicator of cytotoxicity. The classical NQO1 inducer sulforaphane served as the positive control.

\section{RESULTS AND DISCUSSION}

The aim of the present work was to design, synthesize and evaluate the NQO1 inducer activity of novel thioureido and quinazoline sulfonamide derivatives (Scheme-I). The reaction of methyl 2-isothiocyanatobenzoate 2 with 4-amino- $\mathrm{N}$-(1phenyl- $1 H$-pyrazol-5-yl) benzenesulfonamide in absolute ethanol at room temperature gave the methyl 2-(3-(4-(N-(1phenyl-1H-pyrazol-5-yl)sulfamoyl)phenyl)-thioueiro)- 
benzoate (3) in good yield. The structure of compound $\mathbf{3}$ was established by elemental analysis, IR, ${ }^{1} \mathrm{H}$ NMR, ${ }^{13} \mathrm{C}$ NMR spectra and X-ray data. The IR spectrum of $\mathbf{3}$ revealed the presence of characteristic bands for $(\mathrm{NH})$ at $3448,3275,(\mathrm{CH}$ aromatic) at $3039 \mathrm{~cm}^{-1},\left(\mathrm{CH}\right.$ aliphatic) at 2977, $2863 \mathrm{~cm}^{-1}$, $(\mathrm{C}=\mathrm{O})$ at $1662 \mathrm{~cm}^{-1},(\mathrm{C}=\mathrm{N})$ at $1620 \mathrm{~cm}^{-1},\left(\mathrm{SO}_{2}\right)$ at 1342,1168 $\mathrm{cm}^{-1}$ and $(\mathrm{C}=\mathrm{S})$ at $1261 \mathrm{~cm}^{-1}$. The ${ }^{1} \mathrm{H}$ NMR spectrum indicated the presence of signals at $4.2 \mathrm{ppm}$ (assigned to $\mathrm{OCH}_{3}$ ), 6.6 and $7.6 \mathrm{ppm}$ due to $2 \mathrm{CH}$ pyrazole, 7.0-8.1 ppm corresponding to the aromatic protons, $11.4 \mathrm{ppm}$ for $\mathrm{SO}_{2} \mathrm{NH}$ and $12.9 \mathrm{ppm}$ for $2 \mathrm{NH}$ groups. The ${ }^{13} \mathrm{C}$ NMR spectrum exhibited signals at: 52.4, 95.6, 121.3 (2), 121.8, 127.9 (2), 128.5 (2), 129.0 (2), $131.4,132.6,134.3,137.8,139.6,141.2,141.8,144.9,168.1$, 181.2.<smiles>COC(=O)c1ccccc1N</smiles>
(1)

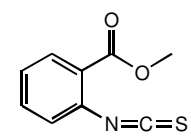

(2)

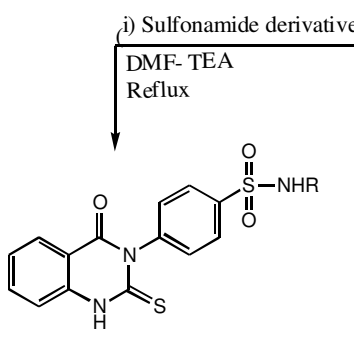

$(4,5)$<smiles>COc1cc(C#[R][Na])nc(OC)n1</smiles>

Scheme-I: Formation of thiouriedo and quinazoline derivatives 3-5

The reaction of compound 2 with 4-amino- $N$-(1-phenyl$1 H$-pyrazol-5-yl) benzenesulfonamide and/or 4-amino- $N$ - $(3,5$ dimethoxy-phenyl) benzenesulfonamide in refluxing absolute ethanol containing a catalytic amount of triethylamine afforded the corresponding 4-(4-oxo-2-thioxo-1,2-dihydroquinazolin3(4H)-yl)- $N$-(1-phenyl-1H-pyrazol-5-yl)benzenesulfonamide (4) and $N$-(2,6-dimethoxypyrimidin-4-yl)-4-(4-oxo-2-thioxo1,2-dihydroquinazolin-3(4H)-yl) benzenesulfonamide (5) in good yield. The structure of $\mathbf{4}$ and $\mathbf{5}$ was confirmed from its microanalysis, IR, ${ }^{1} \mathrm{H}$ NMR, ${ }^{13} \mathrm{C}$ NMR. Thus, IR spectrum of 4 exhibited the presence of characteristic bands for $(\mathrm{NH})$ at $3307,3210 \mathrm{~cm}^{-1},(\mathrm{CH}$ aromatic $)$ at $3088 \mathrm{~cm}^{-1},(\mathrm{C}=\mathrm{O})$ at 1688 $\mathrm{cm}^{-1}$ and $(\mathrm{C}=\mathrm{N})$ at $1610 \mathrm{~cm}^{-1},\left(\mathrm{SO}_{2}\right)$ at $1365,1155 \mathrm{~cm}^{-1},(\mathrm{C}=\mathrm{S})$ at $1272 \mathrm{~cm}^{-1} .{ }^{1} \mathrm{H}$ NMR spectrum of 4 in (DMSO- $d_{6}$ ) revealed signals at 6.4, 7.4 ppm attributed to $2 \mathrm{CH}$ pyrazole, 7.0-8.2 $\mathrm{ppm}$ assigned to aromatic protons, 9.3 due to $\mathrm{NH}$ and $11.4 \mathrm{ppm}$ corresponding to $\mathrm{SO}_{2} \mathrm{NH}$. The ${ }^{13} \mathrm{C}$ NMR spectrum revealed signals at $91.7,119.8(2), 120.6(2), 122.7,124.6,125.1,126.8$ (2), 127.6, 127.9, 128.5 (2), 130.6, 134.1, 134.7, 140.4, 141.3, $141.9,144.8,162.7,187.3$. The IR spectrum of $\mathbf{5}$ had characteristic bands for $(\mathrm{NH})$ at $3216,3194 \mathrm{~cm}^{-1},(\mathrm{CH}$ aromatic) at $3065 \mathrm{~cm}^{-1},(\mathrm{C}=\mathrm{O})$ at $1691 \mathrm{~cm}^{-1}$ and $(\mathrm{C}=\mathrm{N})$ at 1622 $\mathrm{cm}^{-1},\left(\mathrm{SO}_{2}\right)$ at $1357,1163 \mathrm{~cm}^{-1},(\mathrm{C}=\mathrm{S})$ at $1265 \mathrm{~cm}^{-1}$. The ${ }^{1} \mathrm{H}$ NMR spectrum of 5 showed signals at: $3.6,3.7 \mathrm{ppm}$ assigned to $2 \mathrm{OCH}_{3}, 6.2 \mathrm{ppm}$ due to $\mathrm{CH}$ pyrimidine, 7.1-8.2 ppm for aromatic protons, $8.9 \mathrm{ppm}$ attributed to $\mathrm{NH}, 10.9 \mathrm{ppm}$ for $\mathrm{SO}_{2} \mathrm{NH}$. The ${ }^{13} \mathrm{C}$ NMR spectrum exhibited signals at: 56.6 (2), 84.3, 120.8 (2), 122.6, 125.7, 126.3 (2), 126.9, 127.8, 129.8, 134.6, 134.9, 138.4, 161.3, 161.7, 163.2, 174.1, 187.8 .

Biological evaluation: Compound $\mathbf{3}$ had a weak NQO1 inducer activity, elevating the specific activity of the enzyme by 1.38 -fold at $100 \mu \mathrm{M}$, the highest concentration tested (Fig. 1A and Table-1). Compound $\mathbf{4}$ doubled the NQO1 activity at a concentration of $16 \mu \mathrm{M}$. Compound 5 was 3 times more potent than compound $\mathbf{4}$, doubling the enzyme activity at a concentration of $5.2 \mu \mathrm{M}$. However, it was also more toxic as evident by the significant dose-dependent decrease in the protein content of the lysates of cells that had been exposed to concentrations of compound 4 higher than $25 \mu \mathrm{M}$ (Fig. 1B). Taken together with our previous findings that the sulfonamide group by itself is not sufficient for NQO1 inducer activity ${ }^{28}$, these results indicate that introduction of the thioureido moiety confers inducer activity. Furthermore, incorporating the thioureido functionality within a heterocyclic ring system increases the inducer potency substantially.
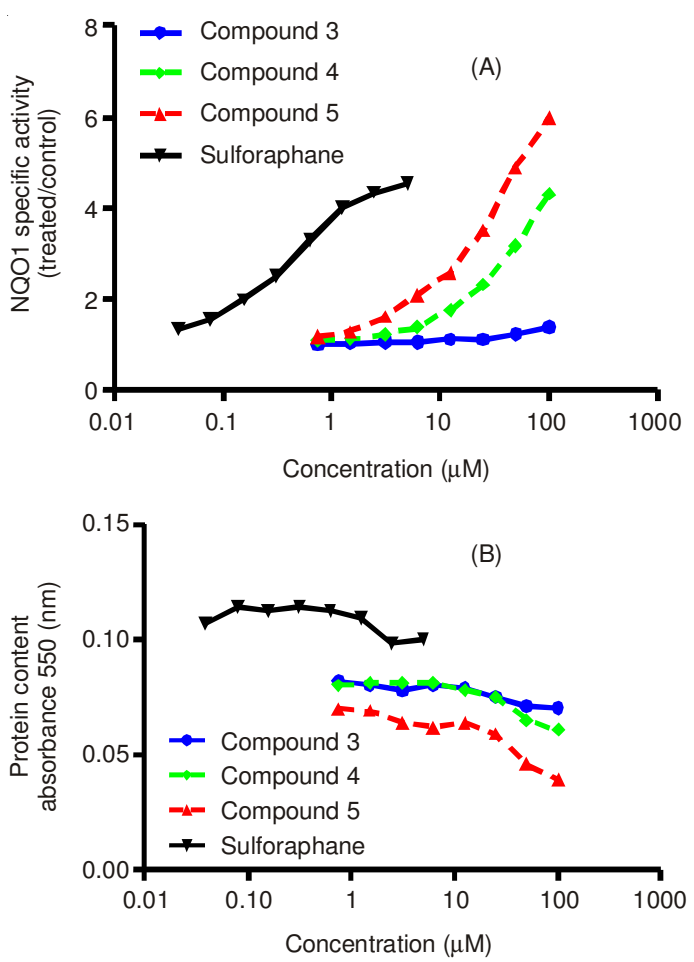

Fig. 1. Dose response of NQO1 inducer activity of thioureido and quinazoline sulfonamide derivatives. Hepa1c1c7 cells $\left(10^{4}\right.$ per well) were grown in 96-well plates for $24 \mathrm{~h}$. The cell culture medium was then removed and replaced with fresh medium containing serial dilutions of compounds. Sulforaphane was used as a positive control. Cells were grown for a further $48 \mathrm{~h}$, and then lysed with digitonin. The specific activity of NQO1 was determined using menadione as a substrate (A). The protein content was measured in each well by the BCA assay (B). Mean values for 8 replicate wells are shown for each data point. The standard deviation for each was $<5 \%$ of the value

Induction of NQO1 by sulfur heterocyclic compounds such as dithiolethiones (e.g. oltipraz) is an effective means for achieving protection against environmental carcinogens ${ }^{41}$. Transcriptional control of the expression of NQO1 is coordinately regulated with more than 100 other cytoprotective proteins 


\begin{tabular}{ccc}
\hline \multicolumn{3}{c}{ TABLE-1 } \\
\multicolumn{3}{c}{ NQO1 INDUCER POTENCY OF THIOUREIDO AND } \\
QUINAZOLINE SULFONAMIDE DERIVATIVES \\
\hline Compounds & $\mathrm{CD}(\mu \mathrm{M})$ & Induction magnitude (fold) \\
\hline $\mathbf{3}$ & Not reached & 1.38 \\
$\mathbf{4}$ & 16 & 4.3 \\
$\mathbf{5}$ & 5.2 & 5.99 \\
Sulforaphane & 0.2 & 4.5 \\
\hline
\end{tabular}

and is mediated through antioxidant response elements (ARE), specific sequences in the upstream regulatory region of the genes encoding these proteins. The transcription factor Nrf2, which binds to the antioxidant response elemnts and its major negative regulator, Keap1, which also serves as inducer sensor, are essential for the basal and/or inducible expression of these genes. It can therefore be proposed that these new thioureido compounds induce NQO1 by modifying cysteine residues in the sensor protein Keap1.

In conclusion, we found that the introduction of a thioureido moiety confers NQO1 inducer activity of sulfonamide derivatives and that the incorporation of this moiety within a heterocyclic ring system increases the inducer potency. Importantly, NQO1 deficiency is associated with a reduced survival after metastasis in breast cancer patients ${ }^{42}$, whereas the NQO1 inducer sulforaphane and three synthetic analogues, which had been designed as potent NQO1 inducers, inhibit the formation of mammary tumors in Sprague-Dawley rats treated with the chemical carcinogen 9,10-dimethyl-1,2-benzanthracene ${ }^{43}$. Moreover, the results from both preclinical and clinical evaluation studies of sulforaphane for chemoprevention in the breast have provided a strong rationale for evaluating the protective effects of this NQO1 inducer in clinical trials of women at risk for breast cancer ${ }^{44}$. In addition, a recent study has reported that combinations of sulforaphane and the aromatase inhibitor exemestane, which is clinically used for prevention and treatment of breast cancers and is also an NQO1 inducer, are synergistic in inhibiting pro-inflammatory response ${ }^{45}$ which play an important role in the pathogenesis of cancer ${ }^{46}$. Thus, our findings encourage the future development of more potent derivatives bearing a thioureido moiety within a heterocyclic ring system as cytoprotective agents for cancer chemoprevention.

\section{ACKNOWLEDGEMENTS}

The authors would like to extend their sincere appreciation to the Deanship of Scientific Research at King Saud University for its funding of this research through the Research Group Project no. RGP-VPP-302. Thanks are also due to Cancer Research UK (C20953/A10270) for financial support.

\section{REFERENCES}

1. M.M. Ghorab, Z.H. Ismail, M. Abdalla and A.A. Radwan, Arch. Pharm. Res., 36, 660 (2013).

2. M.M. Ghorab, Z.H. Ismail, A.A. Radwan and M. Abdalla, Acta Pharm., 63, 1 (2013)

3. M.M. Ghorab, F.A. Ragab, H.I. Heiba and A.A. Bayomi, ArznemittelForschung Drug Res., 61, 719 (2011).

4. M.M. Ghorab, H.I. Zienab and A. Mohamed, Arznemittel-Forschung Drug Res., 60, 87 (2010).

5. A.K. Ashraf, G.A. Sami, M.A. Abdulrahman and I.E. Hussein, Arch Pharm. Pharm. Med. Chem, 2, 95 (2003).

6. M.N. Noolvi and H.M. Patel, Arab. J. Chem., 6, 35 (2013).
7. M.N. Noolvi, H.M. Patel, V. Bhardwaj and A. Chauhan, Eur. J. Med. Chem., 46, 2327 (2011).

8. L.M. Antypenko, S.I. Kovalenko, O.M. Antypenko, A.M. Katsev and O.M. Achkasova, Sci. Pharm., 81, 15 (2013).

9. M.M. Ghorab, E. Noaman, M.M.F. Ismail, Y.A. Ammar, H.I. Heiba and M.Y. Sayed, Arznemittel-Forschung Drug Res., 56, 405 (2006).

10. A.M.Sh. El-Sharief, M.M. Ghorab, M.S.A. El-Gaby, Sh.I. Mohamed and Y.A. Ammar, Heteroatom Chem., 13, 316 (2002).

11. R.J. Hooley, L.M. Scoutt and L.E. Philpotts, Radiology, 268, 642 (2013).

12. S. Gizzo, C. Saccardi, T.S. Patrelli, R. Berretta, G. Capobianco, S.D. Gangi, A. Vacilotto, A. Bertocco, M. Noventa, E. Ancona, D. D'Antona and G.B. Nardelli, Obstet. Gynecol. Surv., 68, 467 (2013).

13. R. Piva, D.A. Spandidos and R. Gambari, Int. J. Oncol., 43, 985 (2013).

14. M.S. Alsaid, M.G. El-Gazzar and M.M. Ghorab, Drug Res. (Stuttg), 63, 263 (2013)

15. M.S. Al-Dosari, M.M. Ghorab, M.S. Alsaid and Y.M. Nissan, Chem. Pharm. Bull. (Tokyo), 61, 50 (2013).

16. M.S. Bashandy, M.S. Alsaid, R.K. Arafa and M.M. Ghorab, J. Enzyme Inhib. Med. Chem., 29, 619 (2013).

17. M.M. Ghorab, F.A. Ragab and M.M. Hamed, Arzneimittelforschung Drug Res., 60, 141 (2010).

18. M.M. Ghorab, F.A. Ragab, H.I. Heiba, H.A. Youssef and M.G. El-Gazzar, Med. Chem. Res., 21, 1376 (2012).

19. M.M. Ghorab, F.A. Ragab, H.I. Heiba, M. El-Gazzar and M. El-Gazzar, Acta Pharm., 61, 415 (2011).

20. K. Brozewicz and J. Slawinski, Eur. J. Med. Chem., 55, 384 (2012).

21. J.M. Calderón-Montaño, E. Burgos-Morón, M.L. Orta, N. Pastor, C. PerezGuerrero, C.A.S. Austin, M. Mateos and M. López-Lázaro, Pharmacol. Rep., 64, 1515 (2012).

22. J. Duo, Y. Ma, G. Wang, X. Han and C. Zhang, DNA Cell Biol., 32, 156 (2013).

23. Y. Genc, R. Ozkanca and Y. Bekdemir, Clin Microbiol Antimicrob., 7, 17 (2008).

24. J.B. Gibbs, Science, 287, 1969 (2000)

25. B.B. Subudhi and G. Ghosh, Bull. Chem. Soc. Ethiopia, 26, 455 (2012).

26. M.M. Ghorab, F.A. Ragab and M.M. Hamed, Arzneimittelforschung Drug Res., 60, 141 (2010).

27. W.R. Chegwidden and I.M. Spencer, Inflammopharmacology, 3, 231 (1995).

28. M.M. Ghorab, M. Higgins, M.S. Alsaid, R.K. Arafa, A.A. Shahat and A.T. Dinkova-Kostova, J. Enzyme Inhib. Med. Chem., 29, 840 (2014).

29. D. Ross and D. Siegel, Methods Enzymol., 382, 115 (2004).

30. A.T. Dinkova-Kostova and P. Talalay, Arch. Biochem. Biophys., 501, 116 (2010)

31. L. Baird and A.T. Dinkova-Kostova, Arch. Toxicol., 85, 241 (2011).

32. A.T. Dinkova-Kostova and R.V. Kostov, Trends Mol. Med., 18, 337 (2012).

33. M.M. Ghorab, F.A. Ragab, H.I. Heiba and R.M. El-Hazek, Eur. J. Med. Chem., 46, 5120 (2011).

34. M.M. Ghorab, F.A. Ragab and M.M. Hamed, Eur. J. Med. Chem., 44, 4211 (2009).

35. M.M. Ghorab, F.A. Ragab, H.I. Heiba, R.K. Arafa and E.M. El-Hossary, Med. Chem. Res., 20, 388 (2011).

36. M.S. Al-Said, M.S. Bashandy, S.I. Al-qasoumi and M.M. Ghorab, Eur. J. Med. Chem., 46, 137 (2011).

37. M.S. Alsaid, M.M. Ghorab, M.S. Al-Dosari and M.M. Hamed, Eur. J. Med. Chem., 46, 201 (2011).

38. M.S. Bashandy, M.S. Alsaid, S.I. Alqasoum and M.M. Ghorab, Arzneimittel-Forschung Drug Res., 61, 521 (2011).

39. M.S. Alsaid, M.S. Bashandy and M.M. Ghorab, Arzneimittel-Forschung Drug Res., 61, 527 (2011).

40. H.J. Prochaska and A.B. Santamaria, Anal. Biochem., 169, 328 (1988).

41. M.K. Kwak, K. Itoh, M. Yamamoto, T.R. Sutter and T.W. Kensler, Mol. Med., 7, 135 (2001).

42. R. Fagerholm, B. Hofstetter, J. Tommiska, K. Aaltonen, R. Vrtel, K. Syrjäkoski, A. Kallioniemi, O. Kilpivaara, A. Mannermaa, V.M. Kosma, M. Uusitupa, M. Eskelinen, V. Kataja, K. Aittomäki, K. von Smitten, P. Heikkilä, J. Lukas, K. Holli, J. Bartkova, C. Blomqvist, J. Bartek and H. Nevanlinna, Nat. Genet., 40, 844 (2008).

43. Y. Zhang, T.W. Kensler, C.G. Cho, G.H. Posner and P. Talalay, Proc. Natl. Acad. Sci. USA, 91, 3147 (1994).

44. B.S. Cornblatt, L. Ye, A.T. Dinkova-Kostova, M. Erb, J.W. Fahey, N.K. Singh, M.S. Chen, T. Stierer, E. Garrett-Mayer, P. Argani, N.E. Davidson, P. Talalay, T.W. Kensler and K. Visvanathan, Carcinogenesis, 28, 1485 (2007).

45. H. Liu and P. Talalay, Proc. Natl. Acad. Sci. USA, 110, 19065 (2013).

46. A. Mantovani, P. Allavena, A. Sica and F. Balkwill, Nature, 454, 436 (2008). 